\title{
THE FIRST OCCUPATION OF VILNIUS DURING THE GREAT NORTHERN WAR (APRIL-MAY 1702)*
}

\author{
Gintautas Sliesoriūnas
}

ABSTRACT This article seeks to reconstruct the military actions and the diplomatic initiatives connected with the first Swedish occupation of Vilnius, the capital of the Grand Duchy of Lithuania, during the Great Northern War.

In this study primary sources were used - the correspondence of the chief leaders of the army of the Lithuanian Republicans. This allowed a revision of previous assertions found in historiography, which were usually based on the diaries and memoirs of contemporaries.

Late in 1701 the Swedish army, led by King Charles XII of Sweden, invaded the Grand Duchy of Lithuania through the Duchy of Courland and soon occupied Žemaitija, Kaunas, the powiat (district) of Upyte and a part of Ukmerge. Shortly afterwards the Swedes took Vilnius under their control. The occupation of the capital of Lithuania and the battle that followed (16 April 1701, Easter Sunday) was one of the most remarkable events in the course of the Northern War on the territory of the GDL. The occupation of Vilnius was significant not only from the military point of view: supported by the Swedes, the Lithuanian Sapiega nobles returned to the capital. In the 1680s and 1690s having attempted to monopolize power in their hands, they had been driven out after their defeat by the armed opposition in the battle of Valkininkai on 18 November 1700. Swedish military support gave the Sapiegas an advantage over their opponents the Lithuanian Republicans at the helm of state after the battle of Valkininkai, and the control of the capital should have enhanced the chance of reestablishing their political influence in the state. However, the military logic and interests of Charles XII ignored Sapiegas' interests and they had to retreat from Vilnius.

* This is a revised and supplemented version of my article 'Pirmoji Vilniaus okupacija Šiaurès karo metais (1702 m. balandis-gegužè)', Praeities pédsakais, dedicated to the 65th birthday of Professor Zigmantas Kiaupa (Vilnius, 2007), pp. 267-292. 
The manoeuvres of the principal military units led by Charles XII, August II, Peter I and their chief commanders have been investigated very thoroughly. Meanwhile the military actions outside the main theatre of operations - the movements of Sapiegas' troops, their Swedish allies and the struggle against the Lithuanian Republicans - have not yet been researched properly. The historians ${ }^{1}$ who wrote about the first occupation of Vilnius usually based their accounts on various memoirs and diaries. ${ }^{2}$ Consequently, their works contained numerous inaccuracies and mistakes.

The present article aims at reconstructing a more accurate picture of the military operations and diplomatic initiatives related to the first occupation of Vilnius during the Northern War on the basis of primary sources. They are the correspondence between the chancellor of Lithuania Karolis Stanislovas Radvila (Karol Stanisław Radziwiłł) and the leaders of the Lithuanian Republicans' army the Field Hetman of Lithuania (since the early 1702) and Colonel general of Lithuanian palatinates, powiats and of the army Mykolas Servacijus Višnioveckis (Michał Serwacy Wiśniowiecki), and the grand notary of Lithuania Liudvikas Konstantinas Pociejus (Ludwik Konstanty Pociej). ${ }^{3}$ At that time the chancellor acted as an intermediary between the Lithuanian Republicans and King August II. The chancellor was regularly and in detail informed about both conducted and planned

${ }^{1}$ J.I. Kraszewski, Wilno od poczatków jego do roku 1750, t. 2 (Vilnius, 1840), pp. 82-83, 171-173; A. Przezdziecki, Podole, Wotyń, Ukraina, t. 1 (Warsaw, 1841), p. 99; E. Tyszkiewicz, Listy o Szwecji, t. 2 (Vilnius, 1846), pp. 176-178; K. Jarochowski, Dzieje panowania Augusta II od wstapienia Karola XII na ziemię Polska aż do elekcyi Stanisława Leszczyńskiego (1702-1704) (Poznań, 1874), p. 41; L. Piechnik, Dzieje Akademii Wileńskiej, t. 3 (Próby odnowy Akademii Wileńskiej po klęskach Potopu i okresu kryzysu 1655-1730) (Rome, 1987), pp. 98-99; B. Dundulis, Švedu feodalu isiveržimai i Lietuva XVII-XVIII a. (Vilnius, 1977), pp. 120-121.

2 J. Oleszewski, Abrys domowej nieszczęsliwości (...) wyrażony Anno 1721 (Cracow, 1894); [K. Zawisza], Pamiętniki Krzysztofa Zawiszy, wojewody mińskiego (1666-1721), ed. J. Bartoszewicz (Warsaw, 1862), pp. 212-214; a fragment of these memoirs about the events in Vilnius in 1702 was translated into Lithuanian and published in: Lietuvos TSR istorijos šaltiniai, t. 1 (Vilnius, 1955), pp. 315-316; L. Piechnik's writings about the 1702 events in Vilnius were based on the chronicle of the University of Vilnius Historia Collegii Vilnensis, kept in the Archive of the Jesuit Order in Rome Archiwum Romanum Societatis Iesu, Polonica \& Lithuanica, 44.

${ }^{3}$ L.K. Pociejus' letters to K.S. Radvila, Archiwum Główne Akt Dawnych, Archiwum Radziwiłłów (henceforth - $A G A D, \mathrm{AR}$ ), V, nr. 11913 / I; M.S. Višnioveckis' letters to Radvila, $A G A D$, AR, V, nr. 17503 / I. 
military operations (e.g. the intended attack of Vilnius over Easter); he used to receive letters even when he did not answer them ${ }^{4}$ (mostly due to the disarray of the postal service or war-time difficulties for couriers). Supported by the chancellor the leaders of the Lithuanian Republicans not only informed the king about the progress of military operations and got financial and material support but also influenced the king's policy and appointments to high posts (e.g. of Polish hetmans); they also advised him on how to avoid mutiny in the army of the Kingdom of Poland (that the army would not back August II's dethronement suggested by Charles XII and the Polish opposition). ${ }^{5}$ All that shows that this correspondence was a most significant source revealing the actions and motives of the leaders of the Lithuanian Republicans.

The Eve of the Occupation of Vilnius At the beginning of 1702 the Republic of Poland-Lithuania officially was not yet at war with Sweden. Swedish intervention was formally directed only against King August II as the Saxon elector and against one of the leaders of the Lithuanian Republicans, the starosta general of Žemaitija Grigorijus Antanas Oginskis (Hrehory Antoni Ogiński). The latter already in 1701 began to attack the Swedes in the Duchy of Courland and in Žemaitija where he was persecuted by Swedish troops. Although early in 1702 the conflict exacerbated the situation, the majority of Polish senators and a number of Lithuanian senators hoped to cope with the situation peacefully and avoid a war; a delegation of the negotiators of the Republic was sent to Charles XII. At the same time, nevertheless, the army of the Lithuanian Republicans was getting ready for a serious counter-attack against the Swedes.

4 'Wydziwić się nie mogę, że na tak wiele listów naszych tak długo od Waszey Xciey Msci żadney nie mamy wiadomości‘, Pociejus to Radvila, letter of 14 Apr. 1702 from the military camp, ibid., nr. 11913/ I, pp. 104-106 (in the article the quotations of the sources are edited by the author only minimally).

${ }^{5}$ Pociejus to Radvila, letter of 30 May 1702 from the camp at Bokštai, ibid., pp. 119-122. The leaders of the Republicans feared that a mutiny could break out in the Polish army against August II, the more so that at that time both posts of Polish hetmans were vacant. They proposed to appoint the starosta of Halicz Józef Potocki to the post of the field hetman of Poland - he would ensure the army's submission, and the most influential noblemen, expecting the post of the grand hetman, would be loyal to the king. L.K. Pociejus stressed that the Lithuanian Republicans placed most confidence in none other than the starosta of Halicz. Incidentally, he was appointed grand hetman of Poland by Stanisław Leszczyński, a Swedish stooge, in 1706. 
L.K. Pociejus informed the Lithuanian chancellor that Višnioveckis was going to simulate an attack of the Republican army from Grodno in the direction of Kaunas, but he would not like a clash with the Swedes before his linkup with the troops led by Oginskis. To the knowledge of Višnioveckis and L.K. Pociejus, these troops were to be reinforced shortly by Ukrainian Cossacks sent from Russia. The incursion into Žemaitija was planned with joint forces. The operation had to succeed since according to information received by the Republican leaders the Swedes had divided their forces along the line Kaunas, Kédainiai, Jurbarkas, Raudone, etc. deploying several thousand troops in each locality. ${ }^{6}$ The march of Višnioveckis' division from Grodno towards Kaunas was crowned with success in the battle against the Swedes at Darsūniškis on 14 March 1702. The Lithuanian field hetman was resolute and sure of the correctness of his actions. Foreseeing that he would be accused of provoking a war with Sweden Višnioveckis wrote to the Lithuanian chancellor that he did not fear the accusation of the lords of the Crown at all because he behaved honestly by following the example of his ancestors and defending his fatherland against the enemy. Meanwhile their Graces (i.e. Polish senators sympathizing with the Sapiegas) would be ashamed in the face of the entire Republic because they invited the enemy into their country. ${ }^{7}$ At the same time the leadership of the Lithuanian Republicans intensified their efforts to obtain financial and military support in Moscow. All that proceeded with the knowledge and approbation of August II but behind the back of the politicians of the Kingdom of Poland. ${ }^{8}$

6 'Xże Je ${ }^{o}$ msc Hetman spod Grodna woysko ruszy niby ku Kownowi, ale z tey strony Niemna, ale żadney ieszcze imprezy nie wtrzyma aż się złączy z Je ${ }^{0}$ mcią Panem Starosto Żmudzkim, który już miał złączyć z Kozakami. Skupiwszy tedy iuż woyska na znaczno iako razem odważymy się impreze y nadzieja w Bogu, że możemy dobrze goscić, ponieważ nieprzyiaciel rozłożył się po kilku tysięcy tilko po rużnych mieyscach, iako to w Kownie, Kieydanach, Jurborku, Raudany etc. y lynio się położył, a że ku Żmudzi niepodobna tedy żebyśmy nie mieli którykolwiek partyi przerząc, Pociejus to Radvila, letter of 24 Feb. 1702 from Rechitsa (palatinate of Brest Litovsk), ibid., pp. 89-92.

7 'Cale się Ichmsciów Panów Koronnych nie boię aklamacyi, za to, że podciwie z antenatów moich Oyczyznie służąc poszedłem naprzeciwko inwazora Oyczyzny. Barzi się Ichmosc in face całey R. Pospolitey będo wstidzili, którzi wprowadzili tego nieprzyiaciela', Višnioveckis to Radvila, letter of 22 March 1702 from the military camp, ibid., nr. 17503 / I, pp. 25-28.

8 'Żeby ten interes Moskiewski iako nayprędzey był expediowany y skutek swoy odebrał, na którą expedicio ia tu oczekiwam od Waszey Xciey mśći, będzie ochota większa w ricerstwie iak będą posileni', Pociejus to Radvila, letter 
The battle of Darsūniškis intensified military operations. Višnioveckis perceived that he rather than Oginskis was the main Swedish target. Therefore he sought to link up with the starosta of Žemaitija's division at that time mustered in the powiat of Ašmena. After the link-up he planned inroads into Žemaitija. ${ }^{9}$ Višnioveckis' forces retreated to Ašmena through Vilnius, and thus the capital of Lithuania found itself in the centre of Swedish attention. Incidentally the occupation of Vilnius had already been planned earlier. The soldiers taken prisoner in the battle of Darsūniškis and their general Alexander Humerhelm confessed under interrogation that the Swedes had planned a march from Kaunas to Vilnius without delay. Višnioveckis wrote the chancellor of Lithuania that Charles XII, at that time staying in the Bilevičius estate in Žemaitija, was waiting for the Sapiegas there and then all of them had to march towards Vilnius. ${ }^{10}$

Swedish historical sources and scholarship allow us to maintain that the intentions of the Sapiegas and the Swedes concerning the capture of Vilnius were not identical. ${ }^{11}$ The Swedes intended to gather a great contribution sufficient to sustain a large army. The Sapiegas intended to use the Supreme Tribunal of the GDL for the restoration of their power in Lithuania.

Gustaf Jonasson says that GDL treasurer Benediktas Povilas Sapiega (Benedykt Paweł Sapieha) gave Charles XII many suggestions. The king was to issue a declaration in which he would explain why his army entered the Polish-Lithuanian Commonwealth and that he laid no claim on the territory of the Commonwealth. The Swedes were also reveal what they knew of Augustus II's contacts with the tsar. The treasurer also emphasized the importance of continuing the advance. Contributions should be collected with the utmost care. The Sapiega estates should be spared, as well as the estates of Cardinal

of 24 Feb. 1702 from Rechitsa, ibid., nr. 11913 / I, pp. 89-92; В. Д. Королюк, 'Начало шведской агрессии против Речи Посполитой в ходе Северной войны (1701-1702 гг.)', Ученье записки института славяноведения АН СССР, vol. 6, 1952, pp. 270-271.

${ }^{9}$ Višnioveckis to Radvila, letter of 25 March 1702 from Stakliškès, AGAD, AR, V, nr. 17503 / I, pp. 29-38.

10 'Krul Swecki w Bielewiczach, tam na Jm Panów Sapiehów czeka, maio iść do Wilna', ibid.

${ }^{11}$ I express my deepest gratitude to Mr Bengt Nilsson from Linkoping University Library for his assistance which allowed me to use Swedish historiography and historical sources. 
Michał Radziejowski near Warsaw. The treasurer also asked for muskets and Swedish troops in order to force the election of suitable candidates to the tribunal at Vilnius. He also proposed that a future treaty between Sweden and the Republic should include the paragraphs about the removal of Oginskis as starosta of Žemaitija and the well being of the Sapiega family. A couple of days later the treasurer sent an envoy to Carl Piper for the king's reply. On 5 April (Swedish Style) Piper sent the king's reply. He stated that further declarations were unnecessary, he had already made his intentions clear several times in his letters and declarations. Letters to Crown Hetman Stanisław Jablonowski and Cardinał Michał Radziejowski were written in accordance with the treasurer's proposals and the treasurer should inform them that 20,000 and 10,000 reichtsthaler were allotted for them in Riga. As for the use of Swedish forces the king had ordered Colonel Kruse, who would remain in Žemaitija, to cooperate with Hetman Sapiega. Already on 28 March (Swedish Style) Charles XII had ordered the commander of the 'Smelands kavalleriregemente' to march with his regiments and the Vösterbotten and Kalmar infantry regiments to Vilnius. However, day after day passed without any news of Carl Nieroth. In the meantime an order arrived from the king, instructing General Carl Gustaf Mörner to march on Grodno. Mörner's situation grew worse by the day. After the fight on 6 April no supplies could be brought into the city as both Swedish and GDL forces, which supported king August II, had devastated the surrounding countryside. The soldiers started to fall ill and the inhabitants of Vilnius were less than friendly after having paid a large contribution. Mörner's intention was to leave Vilnius as soon as Nieroth arrived, and he made appropriate preparations for the provisioning of the men. However, a new order from the king arrived, instructing Mörner to stay at Vilnius for the time being in order to protect the Sapiegas and safeguard Swedish interests. At the same time Hetman Sapiega arrived with some of his forces and on 20 April (Swedish Style) Nieroth and his three regiments, too. ${ }^{12}$

Yet the first intention of the Swedish king was to gather a great contribution. On 9 March (Swedish Style) 1702 Charles XII issued an order to Mörner. This instructed him to move with his own and Magnus Stenbock's regiment to Vilnius and the Ukmergè (Wilkomierz)

${ }^{12}$ Gustaf Jonasson, Karl XII:s polska politik 1702-1703 (Stockholm, 1968), pp. $36-40$. 
districts where he should 'collect supplies for 40,000 men for two or three months, spreading the rumour that the army would shortly follow'. Upon receiving this order on 11 March (Swedish Style), Mörner immediately went to Naujamiestis to start the march, while Stenbock remained near Ukmerge to prepare the collection of contributions and the construction of bridges across the river Šventoji. ${ }^{13}$ The letter of Magnus Stenbock, written from Ukmerge on 13 March (Swedish Style), confirms, that Charles XII had ordered his army to place the whole districts of Vilnius and Ukmerge under contribution in order to be able to feed 40,000 men. The Swedish forces started their march. The commissar General Jöran Adlersteen was appointed by Charles XII to handle the contribution. ${ }^{14}$

Mörner moved from Naujamiestis past Ramygala to Ukmerge, where he joined Stenbock, and they then continued to Maišiagala and reached Vilnius on 26 March (Swedish Style). After being informed that Mörner had been 'disturbed' by forces under Oginskis and Višnioveckis during his march to Vilnius, on 28 March (Swedish Style) the king ordered Major General Carl Nieroth to march from Kedainiai to Vilnius with the Småland cavalry regiment and the Västerbotten and Kalmar infantry regiments. ${ }^{15}$ During his march Mörner received the assistance of Sapiegas' supporters among the Lithuanian nobility. While marching day and night towards Maišiagala, he wrote to the marshal of Upyte district Aleksander Jan Podbereski to collect a few hundred peasants in Musninkai and build a bridge there, and that was done. ${ }^{16}$

The Occupation of Vilnius Even being aware of Swedish intentions beforehand, Višnioveckis was totally unprepared for the defence of Vilnius. The corps of Mörner attacked the capital of Lithuania

${ }^{13}$ Carl von Rosen, Bidrag till kännedom om de händelsser, som närmast föregingo svenska stormaktsväldets fall, Forsta delen (vol. 1): Sveriges ställning in Polen 1701-1704 (Stockholm, 1936), pp. 29-30.

${ }^{14}$ Handlingar ur v. Brinkman'ska archivet på trolle-ljungby, utgiftne ap Gystaf Andersson, Andra delen (vol. 2) (Örebro, 1895), p. 155.

${ }^{15}$ Carl von Rosen, Bidrag, pp. 29-30, 33-34.

${ }^{16}$ Mörner's report on his expedition to the GDL, see 'Generalmajoren friherre Carl Gustaf Mörners underd. berättelse om sina krigsföretag 25. febr.-9 juli 1702', Karolinska krigares dagböcker jämte andra samtida skrifter, vol. 8 (Lund , 1913), pp. 1-15; information about Podbereski, see p. 5. 
and occupied it on 5 April 1702. ${ }^{17}$ Suffering losses the army of the Lithuanian Republicans retreated hastily. Višnioveckis' main forces were concentrated at Parudaminys. On the eve of the Swedish invasion the field hetman of the GDL arrived in Vilnius with his officers. Here he learned that the Swedes were already in Šrvintos (the parish priest of Širvintos personally hurried to Vilnius to inform Višnioveckis about the approach of the Swedes). Višnioveckis ordered the evacuation of the city (the arsenal and officials), appointed the castellan of Vitebsk Kazimieras Aleksandras Pociejus (Kazimierz Aleksander Pociej) to organize the defence of Vilnius, detailed about 200 dragoons and troopers (Pol. rajtarzy) led by Teider for the guard of the bridge across the Neris and himself in the evening returned to the camp of the main forces at about three miles from the city. After a forced night march the first Swedish units appeared at the stone bridge at dawn. Not expecting the enemy, its defenders retreated without offering resistance (afterwards there were attempts to bring Teider to justice but he managed to evade responsibility stating that K.A. Pociejus, responsible for the defence, did not give an order to defend the bridge. The Swedes took the gates of the city and began arresting the officers and officials of the Republican army staying overnight in the city. K.A. Pociejus himself scarcely managed to escape. The Republicans had good luck because the Swedish forces were too small to block all gates of the city at once and search it. When the Swedes were assembled in the Town Hall square, the majority of the Republican military slipped through the town wall. ${ }^{18}$ The loss of the capital of Lithuania disappointed and upset King August II who hoped to reach an agreement with the Swedes. ${ }^{19}$ L.K. Pociejus endeavoured

${ }^{17}$ Historical literature sometimes indicates other dates of the occupation of Vilnius, e.g. 3 April, see J. Jurginis, V. Merkys, A. Tautavičius, Vilniaus miesto istorija nuo seniausiu laiku iki Spalio revoliucijos, Vilnius, 1968, p. 175; in an eighteeth-century manuscript account the date of the capture of Vilnius is 5 April 'Król szwedzki od Nowego Miasta na Kieydany ordynował jenerała Mernera, który miał 8000 z sobą woyska szwedzkiego z piechotami, z jazdą y kilku sztuk armaty polney do Wilna [...], który stanowszy 5 April. W Vilnie z P. Wdą Wileńskim Wilno wzięli w gubernią swoią, $L M A B$ RS, f. 17, b. 177, fo. 327.

${ }^{18}$ An account of the occupation of Vilnius, 05 (?) Apr. 1702, LMAB RS, f. 17, b. 177 , fos. $325-325 \mathrm{v}$.

19 'Zalterowało go [August II - G. S.] sensibiliter to opanowanie Wilna, turbuie naznaczona audientia Posłów Rzeczyp., bo z tych circumstantiey łatwo colligere, dokąd zamierza Król Szwedzki', Piotr Ernest Kczewski, superintendant of Poland's grand chancery, to Radvila, letter of 10 Apr. 1702 from Warsaw, $A G A D$, AR, nr. 6589 , pp. 66-72. 
to justify such a hasty retreat to the chancellor of Lithuania. He wrote that the Lithuanian military leadership received information that the Swedes were going to encircle Višnioveckis' troops during the defence of the bridge across the Neris. The Swedes, allegedly, intended to involve these troops in the defence of the bridge and eventually the main Swedish forces, led by Charles XII from Kaunas, would attack in the rear and thus encircle Višnioveckis' troops at Vilnius. ${ }^{20}$ The Swedes were known to have seized the arsenal in Vilnius. ${ }^{21}$ L.K. Pociejus' reports show that what was kept in the Vilnius arsenal and went into Swedish hands: Višnioveckis had issued his order to evacuate the arsenal by the Neris and rafts were already loaded with three half-kartouwen (cast still in Władysław Vasa's times), five quarter-kartouwen, three octo-kartouwen and one mortar. Due to a sudden Swedish attack these thirteen cannon could not be evacuated. ${ }^{22}$

From Vilnius Višnioveckis' division retreated to the powiat of Ašmena, to Župronys, Krèva, Alšènai and finally to Smurgainiai, where it linked with Oginskis' troops. ${ }^{23}$ The state of the Lithuanian Republican army was appalling, the soldiers and especially horses were exhausted and hungry. Through the chancellor of Lithuania the Republican leaders asked King August II for help or at least advice on how they should act and reproached him with leaving them to their own devices as if they had not fought for August II (i.e. for his right to the throne of the Republic of Poland-Lithuania). ${ }^{24}$ At that time it was believed that Charles XII himself, attended by the homebound palatine of Vilnius grand hetman of Lithuania Kazimieras Jonas Sapiega (Kazimierz Jan Sapieha), would come to Vilnius. ${ }^{25}$

${ }^{20}$ Pociejus to Radvila, letter of 7 Apr. 1702 from Ašmena, ibid., nr. 11913 / I, pp. 100-103.

${ }^{21}$ Dundulis, Švedu feodalu isiveržimai..., p. 120. Višnioveckis had no time to evacuate the arsenal and many weapons and trains fell into enemy hands.

${ }^{22}$ Pociejus to Radvila, letter of 7 Apr. 1702 from Ašmena, AGAD, AR, V, nr. 11913 / I, pp. 100-103.

${ }^{23}$ An account of the retreat from Vilnius, LMAB RS, f. 17, b. 177 , fo. $325 \mathrm{v}$.

24 'Dla Boga [...], z Warszawy nullum subsidium nec in consilyis, nec in aere, właśnie iakbyśmy nie mieli Pana y nie o niego chodziło, cale nie wiemy, co czynić sami, serce nam upada, kiedy cos tak oziembłego widzim Krula [...]', $A G A D, \mathrm{AR}$, V, nr. 11913 / I, pp. 100-103.

${ }^{25}$ Ibid. 
Having occupied Vilnius and established the camp of their army in the suburb of Šnipiškès on the right bank of the Neris (at the stone bridge), the Swedes initially behaved exceptionally reservedly in order to ingratiate themselves with the inhabitants and the ecclesiastical authorities of the city. Nevertheless they tried to confiscate the riches of the Sapiegian enemies hidden in monasteries, but they did not do that under duress. In the morning and in the evening the Swedes would come to the University church to listen to the Holy Week Lamentations (wielkotygodniowe 'lamentacye'). ${ }^{26}$ Such were Swedish tactics - to show that Sweden was fighting not against the Republic of Poland-Lithuania but against August II as the Saxon elector and concrete noblemen who supported the king in the war against Sweden. Circumspect behaviour by those who were not in opposition to the Swedes helped the Sapiegas as Swedish allies to rally their adherents and regain their influence as well as to encourage the opposition in Poland to stand resolutely against king Augustus II. However, any active resistance was met by the Swedes with repression and emaciating reparations. Soon Vilnius, too, fell into disfavour.

After the retreat from Vilnius the Republican troops linked up with Oginskis' forces at Smurgainiai on 13 April 1702. The Republican leaders considered that it was senseless laying hopes on the talks with the Swedes because after the visit of their envoys to Charles XII the Swedes only intensified their attacks. ${ }^{27}$ Having united their forces the Republicans resolved to organize a counterattack. They already knew that the main Swedish troops had moved from Kaunas in the direction of Grodno instead of Vilnius and could be there by 14 April. ${ }^{28}$ Therefore in case of the counterattack in Vilnius Swedish reinforcements could not be expected. Actually at that time Charles XII was in the environs of Punia. The Republican leaders were also aware of the arrival of a part of Sapiegas' forces - the regiments of light cavalry of Boryczewski, Pietrowski and Kącewicz - in Vilnius. In the opinion of the Republicans, the participation of Sapiegas' regiments in joint operations with the Swedes was an undeniable

${ }^{26}$ On the discreet Swedish behaviour in the first days of the occupation, in particular with regard to the Jesuits and the University, see L. Piechnik, Dzieje Akademii Wileńskiej, t. 3, p. 98.

${ }^{27}$ Pociejus to Radvila, letter of 14 Apr. 1702 from the military camp, AGAD, AR, V, nr. 11913 / I, pp. 104-106.

${ }^{28}$ Ibid. 
proof that the Sapiegas not only encouraged the Swedish intervention (according to L.K. Pociejus, everything began with the meeting of the Sapiegas with Charles XII in Smalininkai at Jurbarkas) and not only advised the king of Sweden but also took part literally in military invasions. ${ }^{29}$

The Battle of Vilnius (16 April 1702) Following the outbreak of hostilities around Vilnius, the Republicans lost contact with the chancellor of Lithuania and the king. Despite the absence of information from them the Republican leaders continued to write accounts addressed to the chancellor, among other things in advance informing him of their decision to organize a counterattack (the letter reached the addressee after the event). L.K. Pociejus wrote that the grand notary of Lithuania, Marcijonas Valavičius (Marcjan Wołłowicz), would march from the military camp with 4,000 troops during the night of 14-15 April expecting to attack the Swedes in Vilnius on Easter Sunday, on 16 April. At the same time he asked the chancellor to procure the king's support, especially financial, badly needed to upkeep the army, or at least to get some sort of advice. ${ }^{30}$ Višnioveckis instructed L.K. Pociejus to organize a raid into Vilnius. However, he failed to rally 4,000 troops for this operation. After the raid L.K. Pociejus informed the chancellor that only some 2,000 troops participated in the operation, others could not join due to emaciated horses. ${ }^{31}$ Historians usually indicate a greater number of the attackers $-3,000 .{ }^{32}$ These numbers are based on the reminiscences of the starosta of Minsk Kristupas Zaviša (Krzysztof Zawisza). ${ }^{33}$ However, the starosta of Minsk was an adherent of K.J. Sapiega, a Swedish ally, and his chances of getting exact information about the forces of the Republicans, the then enemies, must have been limited. L.K. Pociejus, on the contrary, was the best informed person about the attack on Vilnius.

The Republican forces attacked Vilnius on 16 April at about 2 o'clock p.m. from three directions: through the Dawn Gate, the Trakai Gate and the Lukiškès suburb. The aim of the manoeuvre in

${ }^{29}$ Ibid.

${ }^{30}$ Pociejus to Radvila, letter of 14 Apr. 1702 from the military camp (with Wołłowicz’s postscript), ibid.

${ }^{31}$ Pociejus to Radvila, letter of 20 Apr. 1702 from the military camp, ibid, pp. 107-110.

${ }^{32}$ Dundulis, Švedu feodalu isiveržimai, p. 120 ff.

33 [Zawisza], Pamiętniki Krzysztofa Zawiszy, p. 212. 
the suburb was to take control of the stone bridge across the Neris where in the suburb of Šnipiškès the Swedes had their camp. Thus, the main Swedish forces could be prevented from engaging in the battles in the city and the retreat of the minor forces to the main camp could be intercepted. L.K. Pociejus managed to implement a part of his conception: the Swedish guards at the city's gates and the main guard (odwach) on the Town Hall square were smashed. The bridge across the Neris was not captured but the retreat of the Swedes from the city to Šnipiškès was blocked for some time.

There are no reliable data about Swedish casualties in Vilnius that day. However, the fact that the attack was conducted during the most important religious festival when the city and its churches were full of Swedes - for the service in the Lutheran church and for the sake of curiosity in the Catholic churches - could doubtless increase the number of the dead. L.K. Pociejus wrote that about a thousand of those Swedes who could not retreat to Šnipiškès were killed - streets and squares were covered with their bodies and many more were to perish in the buildings of the city. The Swedes themselves allegedly lost about a thousand in their ranks after the battle. Neither did L.K. Pociejus know the exact number of Swedish casualties - he expected to obtain reliable information later. ${ }^{34}$

The attackers managed to arrest Sapiegas' trustee Marlin Frederik Kanefer (Canifer), who concluded contracts on behalf of these noblemen with various clients, including the Swedes. L.K. Pociejus was sure that Kanefer organized Sapiegas' negotiations with Charles XII and had to be familiar with all Sapiegas' secrets. During interrogations, according to the custodian of Lithuania, he revealed some of them. ${ }^{35}$

The Swedes which were in the city during the attack had little chance to defend themselves, while the main forces in the Šnipiškeis camp managed to do with the situation, to cross the bridge and start counterattacking. The encounter developed into a real battle in which the Swedes enjoyed a clear superiority over the Lithuanian Republicans. The latter began to retreat from the city. In the turmoil they failed to evacuate two light cavalry cannons ('dziatka') and

${ }^{34}$ Pociejus to Radvila, letter of 20 Apr. 1702 from the military camp, $A G A D$, AR, V, nr. 11913 / I, pp. 107-110.

35 Ibid. 
they went to the Swedes. ${ }^{36}$ The Republican forces retreated to the outskirts at the church of St Stephen and subsequently, the Swedes, however, not leaving the city, let the Republicans withdraw undisturbed to Juodšiliai (?). ${ }^{37}$

L.K. Pociejus stated that about 8,000 Swedes participated in the battle. This number probably is exaggerated at least three times. The casualties of the Lithuanian Republicans were insignificant the number of killed and wounded was about $30 .{ }^{38}$ The data about one's own casualties are usually reliable, although sometimes there is a tendency to conceal one's own losses. Therefore the numbers presented by L.K. Pociejus should be treated as exact or only slightly understated.

In a letter to his wife the participant of the battle Gen. Magnus Stenbock wrote that that day about 50 Swedes perished, mostly those which were in the city intending to buy something from the inhabitants. Meanwhile over 100 Lithuanian Republicans were killed, and two drums and two cannons mentioned in other sources went to the Swedes. ${ }^{39}$ Thus, the data vary considerably; however taking into account that the most objective data are those of one's own side it could be presumed that the Republican casualties were over 30 but not more than 100 and of the Swedes about 50 or slightly more. In his official report on the expedition into the GDL in 1702 Mörner estimated the casualties of the Republicans at 100. The Swedish

36 ‘...] dwie armatki w ciasnote ulicy zaprowadzono, że ich salwować y reiterować niepodobna było, te się dostały Szwedowi', ibid.

37 ، [... litewscy wyprowadzili pod S. Stephana Szwedów, ale Szwedzi od mura y parkanów w pole nie wychodząc długo stali, polskie choragwie nie nacieraiąc na lud ognisty odstąpili aż do Czarney na noc o mil 2 od Wilna', LMAB RS, f. 17, b. 177 , fo. $326 \mathrm{v}$.

${ }^{38}$ Pociejus to Radvila, letter of 20 Apr. 1702 from the military camp, $A G A D$, AR, V, nr. 11913 / I, pp. 107-110; other sources indicate quite fantastic data about the casualties in the battle of Vilnius, e.g., 700 killed Swedes and only 5 Republicans. Vilniaus kautynių aprašymas, $L M A B$ RS, f. 17, b. 177, fo. 326v.

${ }^{39}$ Z. Łakociński, Magnus Stenbock w Polsce. Przyczynek do historii szwedzkich zdobyczy w czasie wojny Pólnocnej (Wrocław etc., 1967), p. 30. The author refers to M. Stenbock's letter of 8 (18) Apr. 1702 to his wife Eva Oxenstierna from Vilnius, published in C. M. Stenbock, Magnus Stenbock och Eva Oxenstierna. En brefväxling, I, nr. 294. For comparison: Mörner i Wilna och hans uppbrott derifrån, pp. 34-36, in: Carl von Rosen, Bidrag till kännedom om de händelser, som närmast föregingo svenska stormaktsväldets fall, Första delen: Sveriges ställing till Polen 1701-1704 (Stochholm, 1936). 
general indicated an exaggerated number of the attacking Republican forces $-4,000$ - almost twice as many as in actual fact. ${ }^{40}$

In L.K. Pociejus's opinion, the sortie against the Swedes in Vilnius was rather successful because it was timed in accordance with the most appropriate date. He was sure that if all Lithuanian Republican forces mustered in the Smurgonys camp had participated in the operation, the Swedes in Vilnius would have lost the battle and the whole Mörner's corps would have been crushed. However, 'probably God had chosen another date for the defeat of the Swedes'. ${ }^{41}$

After the battle of Vilnius L.K. Pociejus' troops withdrew towards Ivija, the place of the concentration of the former Višnioveckis' army. There the horses could have rest and the movements of the Swedish troops would be watched. The Republican leaders had already been informed that Charles XII was planning a march from Grodno to Warsaw and the dethronement of August II. ${ }^{42}$ That situation let the Republican leaders to engage in the re-establishment of the military preparedness of their army. The chancellor was once again asked to persuade the king to appreciate the loyalty of the Republicans and to render assistance, in particular financial, since "hungry soldiers would not be able to continue fighting; it is a miracle that they have still been fighting without being salaried'. ${ }^{43}$

Retreating towards Ivija through Alšenai the Lithuanian Republicans stopped for some time at Valazhin. The men and horses were so exhausted that a decision had to be made to limit military operations and stop persecuting the Swedes before the appearance of the spring grass. It was impossible to get fodder. The price of oats rose to 18-20 florins a Vilnius barrel. The Swedes were also confronted with similar problems, but they could confiscate forage in the estates of the gentry what the Republicans still shunned doing at that time. Thus, the Swedish troops had some advantage. ${ }^{44}$

${ }^{40}$ Mörner's report 'Generalmajoren friherre Carl Gustaf Mörners underd. berättelse om sina krigsföretag 25. febr.-9 juli 1702', Karolinska krigares dagböcker jämte andra samtida skrifter, vol. 8 (Lund , 1913), pp. 1-15. The report on battle in Vilnius on 16 (6 - Swedish Style), see pp. 6-7.

${ }^{41}$ Pociejus to Radvila, letter of 20 Apr. 1702 from the military camp, AGAD, AR, V, nr. 11913 / I, pp. 107-110.

42 Ibid.

${ }^{43}$ Ibid; Wołłowicz’s postscript to Pociejus’ letter to Radvila, the military camp on 20 Apr. 1702 , ibid, p. 110. Cf. '[...] niepłatnego naymniey trzy częsci woyska utrzymać sposobu nie mamy'; Wołłowicz’s postscript to Pociejus' letter to Radvila, the military camp on 14 Apr. 1702 , ibid, pp. 104-106.

${ }^{44}$ Pociejus to Radvila, letter of 30(?) Apr. 1702 from the military camp, ibid., pp. 93-99. 
At the end of April the Republican leaders already knew about the intended visit of the envoys of the Republic to Charles XII in Grodno (actually the envoys were received in Ruzhanostok at Grodno on 4 May 1702), but they did not expect any positive results. Charles XII's appeal to the gentry of the Republic inciting the dethronement of August II had already been issued. Therefore, the inaction of the king and Poland baffled the Republican leaders: 'the Republic lies in a malignant lethargic sleep, and even a large-scale invasion of the enemy cannot wake it'. ${ }^{45}$

In historiography there are statements raising serious doubts related to L.K. Pociejus' raid into Vilnius. First, it is an assertion that that raid had to divert the attention and troops of Swedes from another raid led by Višnioveckis himself into Kaunas. This city allegedly was attacked on 17 April 1702, a day later than Vilnius. ${ }^{46}$ In nineteenth-century accounts the attack on Kaunas supposedly conducted by Višnioveckis was described with various details: the city was attacked from the suburb of Vilijampole in the afternoon, the troops invaded the city across the bridge, the inhabitants, warned about the attack beforehand, participated in the battles by shooting at the Swedes from the windows and rooftops, Višnioveckis himself, forced to retreat, scarcely managed to evade capture by leaving the city through the Bernardine monastery. ${ }^{47}$ Meanwhile the correspondence of the Lithuanian Republican leaders presents a quite different picture. The attack of Kaunas is not even mentioned in it. The previously discussed situation showed that the Republican army had been able to muster 2,000 troops instead of 4,000 for the attack of Vilnius, because others (and in particular horses) were too exhausted; consequently the army could hardly undertake one more and even larger operation at the same time. Having joined Višnioveckis several days after the battle of Vilnius L.K. Pociejus wrote that in the battles with the Swedes 'nothing happened after the battle of Vilnius'. ${ }^{48}$ Could the custodian of Lithuania have written

45 Ibid.

${ }^{46}$ A. Przezdziecki, Podole, Wolyń, Ukraina, t. 1 (Warsaw, 1841), p. 99; E. Tyszkiewicz, Listy o Szwecji, t. 2 (Vilnius, 1846), pp. 177-178; Dundulis, Švedu feodalu isiveržimai, p. 121.

${ }^{47}$ Przezdziecki, Podole, p. 99; Tyszkiewicz, Listy o Szwecji, pp. 177-178.

48 'Po odprawioney expedicyi wileńskiey nil novi znowu tentantum dotąd, a to dla barzo znużonych koni w woysku, dla czego Xże Je ${ }^{0}$ mść Hetman zakłada obóz stanowny na niedziel kilka za Iewien nad Niemnem', Pociejus to Radvila, letter of 24 Apr. 1702 from Alšènai, $A G A D$, AR, V, nr. 11913 / I, pp. 111-114. 
like this on 24 April if the battle of Kaunas had taken place on 17 April? On April 22 Višnioveckis wrote his letters from Alšènai, at a distance to the southeast of Vilnius. In his letters he mentioned only excessive fatigue of the men and horses 'after quite successful battles in Vilnius' and reported about his decision to give his forces a rest of several weeks. ${ }^{49}$ In the letter of the field hetman of Lithuania there was no mention about any attack of Kaunas led by him. The general analysis of the military actions of that time calls into question the validity of the attack on Kaunas. The main Swedish forces were deployed to the south of Kaunas (on 17 April 1702 Charles XII was in Merkinè) and in Vilnius there was only a strong Swedish garrison controlling both banks of the Neris. Therefore it is highly improbable that the forces under Višnioveckis could have stolen unnoticed from the former military camp at Smurgainiai, located to the east of Vilnius, to Kaunas and after the battle (on 17 April 1702) could have successfully returned in several days (by 22 April) to the region of Alšenai, Valazhin and Ivija. The analogies in the description of the battles of Vilnius and Kaunas also raise doubts and lead to the conclusion that there was no attack on Kaunas on 17 April 1702 at all. The legend of the attack on Kaunas could appear in the writings of the lovers of history after the amalgamation of the episodes of Višnioveckis' raid into the vicinities of Kaunas in March 1702, the attack on Vilnius led by L.K. Pociejus, and certain narrative sources. The raid on Vilnius led by L.K. Pociejus was the principal rather than secondary military operation of the Lithuanian Republicans reflecting the contemporary military preparedness of the Republican army.

Swedish Repression Another problem requiring revision in the interpretation of the battle of Vilnius is the extent of Swedish repression and reparations in the capital of Lithuania. The character, timing and amount of reparations must be defined more precisely. Revised estimates of Swedish repression could help form a clearer view about the participation of the inhabitants in the battles against the Swedes. As has been mentioned above, initially the Swedes tried to behave correctly. However, this assessment of Swedish tactics

49 'Po odprawionym podiezdzie dość szczęsliwie w Wilnie znużone woysko inakszym nie wiedziałem utrzymać sposobem, tilko opaść konie y na trzy niedziele odpoczą, Višnioveckis to Radvila, letter of 22 Apr. 1702, written at Alšènai, ibid., nr. 17503 / I, pp. 40-43. 
is inconsistent with the statement found in historical works that immediately after the occupation the Swedes began plundering the city and forced the inhabitants to pay reparations - on 10 April, i.e. before the battle of Vilnius, they demanded 22,115 Dutch thalers. ${ }^{50}$ A disagreement arose due to a different dating. The Swedes required to make reparation on 20 April according to the Gregorian calendar as a fine for the support of the inhabitants of the city to L.K. Pociejus. Meanwhile according to the calendar used at that time by the Swedes it was only 10 April. Requirement to make reparations was a usual way of catering to the Swedish army. However, the size of this reparation showed that Vilnius was punished for disloyalty. Various sources indicate different sums: in his letter to Radvila L.K. Pociejus indicated as much as 200,000 thalers, ${ }^{51}$ according to the chronicle of the University of Vilnius 30,000 reichsthalers had to be paid. ${ }^{52}$ However, exact data, presented by Józef Ignacy Kraszewski in the nineteenth century were slightly different: in the decree of the Swedish military commissar Jöran Aldersteen (10/20 April 1702) the required sum was 22,115 reichsthaler; of that sum 15,000 had to be paid by the city and the rest by the ecclesiastical institutions and other jurisdictions. ${ }^{53}$ All in all, 148,605 florins and $81 / 3$ groats (i.e. ca. 22,230 thalers) were collected and 1,859 pounds of gunpowder and 2.503 pounds of lead were given. ${ }^{54}$

The news about Swedish repression in the city reached the military camp of the Lithuanian Republicans on 23 April 1702 through fugitive monks of various Vilnius monasteries. In his account of these events L.K. Pociejus mentioned the reparation of 200,000 thalers (a mistake?) to be paid in a week and a half. In order to ensure the payment of the reparations the Swedes arrested two seniors from each monastery and some burgomasters and councillors. To L.K. Pociejus' knowledge, the arrested were enchained and several days kept in a hot bathroom, in which the corpse of a dead Swede was thrown. At the same time the Swedes began searching monasteries for their treasures (szacować klasztory kazano).

${ }^{50}$ Dundulis, Švedu feodalu isiveržimai, p. 120.

${ }^{51}$ L.K. Pociejus to Radvila, letter of 24 Apr. 1702 from Alšènai, AGAD, AR, V, nr. 11913 / I, pp. 111-114.

${ }^{52}$ Piechnik, Dzieje Akademii Wileńskiej, t. 3, p. 99.

${ }^{53}$ Kraszewski, Wilno od poczatków jego, pp. 172-173.

${ }^{54}$ Ibid., pp. 171-172: Information in the archive of Vilnius city council about raising the reparations for the Swedes (10 Apr. 1702 according to the Julian calendar). 
The inhabitants of the city 'took to the woods and hills'. Many students of the University having fled the city and being unable to reach their native places occupied by the enemy followed in the wake of the Lithuanian Republican army. Besides, the Swedes ordered the gentry of Vilnius powiat to collect six thalers and a ration from each hearth. A similar decree was prepared by the Swedes for the gentry of the powiat of Ašmena, but its promulgation was delayed because this powiat still belonged to the Republican forces. ${ }^{55}$

The Swedes interrogated the inhabitants of Vilnius suspected as accomplices of L.K. Pociejus' troops. The Vilnius Jesuit superiors were questioned by Gen. Magnus Stenbock. The majority of the interrogated persons pinned the blame on the students of the University of Vilnius. ${ }^{56}$ Finally the Swedes hanged about ten inhabitants of the city belonging to a lower stratum of the population. ${ }^{57}$ The extent of repression shows that the inhabitants and students of the city actively participated in the struggle. More active burghers and students avoided severe repression, despite their activities in the battle of Vilnius accentuated in the sources and historiography.

The news about Swedish repression reached the court of August II and Poland. Possibly for propaganda reasons the events in Vilnius were presented as the persecution of Catholics by Lutheran aggressors. ${ }^{58}$ In oral tradition the religious aspect of the battles of Vilnius was reinforced by the story of a miracle on Good Saturday: on 15 April, i.e. on the eve of the battle of Vilnius, a blast of wind allegedly destroyed the gates of the Dawn Gate. That was seen as an omen of victory over the Swedes. Through this gate on Easter

${ }^{55}$ Pociejus to Radvila, letter of 24 Apr. 1702 from Alšènai, $A G A D$, AR, V, nr. 11913 / I, pp. 111-114. In his memoirs Zawisza wrote the superiors of the monasteries, burgomasters and councillors were taken into custody, [Zawisza], Pamiętnik Krzysztofa Zawiszy, pp. 212-213; according to the University chronicle the arrested were kept 'in a small house' in which the corpse of a Swedish officer was thrown, Piechnik, Dzieje Akademii Wileńskiej, t. 3, p. 99. Such behaviour with the body of a Swedish officer is doubtful.

${ }^{56}$ Piechnik, Dzieje Akademii Wileńskiej, t. 3, p. 99.

57 [Zawisza], Pamiętnik Krzysztofa Zawiszy, pp. 212-213: 'wreszcie dziesiątek pospolitego stanu (minoris conditionis) obieszono'.

58 'W Wilnie nie po chrześciańsku grassuią, gdzie w kościołach Katholickich nabożeństwa Luterskie odprawiaią, od Duchownych y zakonników pogłówne wybieraią, ba y samym Pannom zakonnym nie przepuszczaią y po ostatniey actiey z Partyą Litewską, która wpadła była do Wilna y srodze ich potarasowała, vindictam spirantes Szwedzi crudeliter saeviunt', Kczewski to Radvila, letter of 4 May 1702 from Warsaw, $A G A D$, AR, V, nr. 6589, pp. 81-89. 
Day troops led by Antoni Nowosielski entered the city. It was stated that subsequently Nowosielski donated the first votive offering to the Mother of God of the Dawn Gate. ${ }^{59}$ In the eighteenth century the picture of the Mother of God of the Dawn Gate became the most venerated image in Lithuania.

\section{Sapiegas' Endeavour to Consolidate their Rule in Vilnius and} Lithuania During the battle of Vilnius the Sapiegas were not in Vilnius. The grand hetman of Lithuania K.J. Sapiega, the grand treasurer B.P. Sapiega and the steward Jurgis Stanislovas Sapiega (Jerzy Stanisław Sapieha) kept Easter in Kaunas and after the festivities went their own ways. The hetman went to Vilnius, the treasurer to Charles XII's army and the steward continued to muster Sapiegas' forces in the region of Derechin, Slonim and Brest Litovsk. ${ }^{60}$ The GDL hetman arrived in Vilnius not only with his forces but also with Mörner's reinforcements. Mörner had received first reinforcements already before the Pociejus' strike on Vilnius. On 10 (1 Swedish Style) April Lieutenant Colonel Ekeblad unexpectedly arrived with a force sent from Bauska (Courland). As Mörner did not consider it wise to allow this force to operate on its own, he let Ekeblad's force join his own. Ekeblad had about 1,300 men from various units and his task was to hunt Oginskis and 'cover the land', but he had gone much further than was intended. The infantry had neither socks nor shoes and the dragoons were also poorly equipped. Mörner tried to re-equip Ekeblad's force collecting contributions in the city. ${ }^{61}$ The hetman Sapiega arrived in Vilnius with his own and Swedish forces under the command of Nieroth. Nieroth's march was remarkably slow. He did not leave Kèdainiai until 13 (3 Swedish Style) April and was then hindered both by poor roads and by problems of feeding his troops. The population was hostile and had fled into the woods. Apart from this, every boat and raft was destroyed in

${ }^{59}$ J. Jurginis, V. Merkys, A. Tautavičius, Vilniaus miesto istorija, p. 176.

${ }^{60}$ In Kaunas the Sapiegas were guarded by Swedish detachments, and in the powiats of Žemaitija, Kaunas, Upyte and Ukmerge the formation of their troops proceeded. At that time the army of the Sapiegas was said to be small, consisting of a regiment of courtiers, about 150 troopers, 250 Tatar cavalrymen, led by captain Boryczewski; captains Mikuta and Burba formed 'walachian' (valakai) cavalry regiments, Account of Sapiegas' activities, March-April 1702, LMAB RS, f. 17 , b. 177 , fos. $325 \mathrm{v}, 326 \mathrm{v}-327$.

${ }^{61}$ Carl von Rosen, Bidrag till kännedom om de händelsser ..., vol. 1, pp. 34-35; vol. 2, pp.63-64. 
the area, so it became very difficult to cross rivers. About $80 \mathrm{~km}$ from Vilnius Nieroth encountered Hetman Sapiega, who was on his way to the city with a small force of Lithuanians. Sapiega wanted to press on ahead of Nieroth and was given 300 horses as an escort. Sapiega arrived in Vilnius on 26 (16 Swedish Style), and Nieroth the following day. The horses had suffered a lot during the march due to a lack of forage ${ }^{62}$. After his arrival to Vilnius after Easter K.J. Sapiega turned to political initiatives of consolidating the camp of Sapiegas' supporters in Lithuania. The Republican leaders were usually informed about the activity of the palatine of Vilnius in the capital by Catholic priests. They reported that K.J. Sapiega and his nephew were escorted by five valakai regiments (light cavalry units mustered by the Sapiegas). These regiments were a reinforcement of the Swedish corps of 4,000 men in Vilnius. In his palace the palatine of Vilnius held a banquet for Swedish officers (probably on Sunday, 23 April). The Republican leaders were particularly interested in K.J. Sapiega's bodyguard. It consisted of Swedes rather than the citizens of the GDL. The Swedes did not allow him to stay overnight in his palace; instead they used to take him to their camp in Šnipiškès for the night. ${ }^{63}$ It was obvious that the Swedes had made a conclusion from L.K. Pociejus' raid. Šnipiškès proved to be a safe and comfortable place for a military camp. Later during the Northern War this camp will be used more than once by both Swedish and Russian troops.

A major event in Vilnius after its takeover by the Swedes and the Sapiegas was a solemn reburial of the equerry of the GDL Mykolas Pranciškus Sapiega (Michał Franciszek Sapieha), the son of the hetman; he was killed by the Republicans shortly after the battle of Valkininkai (18 November 1700). Sapiegas' courtiers and a detachment of Swedish soldiers carried the equerry's remains from Valkininkai to Vilnius. A solemn divine service took place in the church of St Casimir. The ducal mitre, put on the coffin, was supposed to remind the people that the emperor had conferred that title on the deceased (the entire house of Sapiegas had been conferred that title by the emperor). ${ }^{64}$ Incidentally, two weeks after the murder the body of

\footnotetext{
${ }^{62}$ Ibid., vol. 1, p. 35.

${ }^{63}$ Pociejus to Radvila, letter of 30 (?) Apr. 1702 from the military camp, AGAD, AR, V, nr. 11913 / I, pp. 93-99.

64 'Ciało Nieboszczyka P. Koniuszego Litt' ordynowawszy Szwedzi koni 60 y dworskich niemało odzyskali z Żółkwinik (it must be - Olkienik. - G. S.) do
} 
M.S. Sapiega was embalmed by Sapiegas' doctor Burba specially sent to Valkininkai. The doctor found 63 wounds on the body witnessing a particularly cruel assassination.

The Republican leaders predicted that K.J. Sapiega would try to call a session of the Supreme Tribunal of Lithuania and would use it for their political aims. However, there were doubts that the Sapiegas would gather the necessary quorum of the deputies. ${ }^{65}$ The deputies of the Tribunal supporting the Republicans had retreated to Minsk and there led by the palatine of Trakai Mykolas Kazimieras Katilas (Michał Kazimierz Kociełł) held their own session immediately dissolving it until July due to an extraordinary situation in the country and the total call-up of the gentry (pospolite ruszenie). ${ }^{66}$

The Republican leaders were aware that practically there were no Tribunal deputies in Vilnius. Fourteen deputies of those previously gathered in the capital withdrew to Minsk. There were only those whom the Swedes had brought from Žemaitija and several sympathizers of the Sapiegas. The Minsk starosta Zaviša was a probable Tribunal marshal. Since he was not yet in Vilnius, the deputy of Vilnius powiat Władysław Krasowski was elected marshal, admittedly against his will. Three days later Zaviša was elected marshal. ${ }^{67}$ In his memoirs he stated that the Spiritual Tribunal was also formed and his director was elected sub-steward of Rechitsa Jakub Kazimierz Terebesz/Terebasz Nawojewski. Meanwhile in Minsk no Spiritual Tribunal was formed at all. ${ }^{68}$ However, the Tribunal of Vilnius also ceased functioning after two weeks. ${ }^{69}$ Thus the hopes of the Sapiegas to consolidate their adherents and re-establish their political influence through the Tribunal did not materialize.

Wilna, gdzie u Św. Kazimierza u oo. Jezuitów exeqvie odprawowały się. Mitra leżała na trumnie na pamiątkę deklarowaney od Cesarza Chrześciańskiego Sacri Imperii Mitry, assistencyi tam naywięcey było officerów Szwedzkich', LMAB RS, f. 17 , b. 177 , fo. $327 \mathrm{v}$. L.

${ }^{65}$ Pociejus to Radvila, letter of 30 (?) Apr. 1702 from the military camp, AGAD, AR, V, nr. 11913 / I, pp. 93-99.

${ }^{66}$ Pociejus to Radvila, letter of 14 May 1702 from the environs of Valazhin, ibid., pp. 115-118.

${ }^{67}$ Višnioveckis wrote that 'nearly twenty deputies gathered' in Minsk, Višnioveckis to Radvila, letter of 5 May 1702 from the environs of Valazhin, ibid., nr. 17503 / I, pp. 21-24.

${ }^{68}$ [Zawisza], Pamiętnik Krzysztofa Zawiszy,. p. 213.

69 '[...] jechałem do Wilna na trybunał, na którym miałem dyrekcyą; ale dla pospolitego zamiesznia limitowałem przez dwie niedziele sądząc', ibid., pp. 107-108, 213. 
The Republican leaders considered that having formed a subordinated tribunal K.J. Sapiega would soon transform it into an interregnum court, i.e. he would start administering justice according to the order peculiar to the interregnum periods. ${ }^{70}$ That would mean that the Sapiegas dissociated themselves finally from King Augustus II and treated his dethronement as a fait accompli rather than a programme offered for the gentry. Višnioveckis was certain that Sapiega would behave that way. ${ }^{71}$

However the palatine of Vilnius stopped short of such a crucial step. On the contrary, he even tried to enter into negotiations with the Republican leaders. For the first time after the defeat in the battle of Valkininkai (18 November 1700), K.J. Sapiega probably wanted to exploit a certain advantage gained over his enemies controlling the capital of Lithuania. Asked by Sapiega, the former Bishop Eustachy Kazimierz Kotowicz of Smolensk at that time staying in Vilnius sent his envoys to Višnioveckis. They arrived at the military camp of the Republicans most probably on 29 April and handed in a letter of the bishop of Smolensk ${ }^{72}$ and an invitation of the palatine of Vilnius to the leadership of the Republicans to send authorized persons for negotiations in the capital. The Republican leaders, however, did not accept the invitation and did not reject it altogether. K.J. Sapiega was told that the Republicans recognized the agreements reached with the Sapiegas in the sejm of February 1702 (although actually they refused to implement them after the sejm) and were going to observe them in future. If Sapiega was ready to make peace on other terms he should send his representative to the camp of the Republicans with new proposals which the Republicans would then discuss. ${ }^{73}$ However, this diplomatic initiative of the Sapiegas was not developed further. Like in the principal conflict

70 '[...] fama tu fert, że po ufundowaniu Tribunału y limitaciey zaraz onegoż uczynieniu miał kaptur zacząć', Pociejus to Radvila, letter of 30 (?) Apr. 1702 from the military camp, $A G A D$, AR, V, nr. 11913 / I, pp. 93-99.

71 '[...] asserunt drudzi, czemu ja wierzę, że iusz tanquam sub tempus interregni kaptur sondzić maią, Višnioveckis to Radvila, letter of 5 May 1702 from the environs of Valazhin, ibid., nr. 17503 / I, pp. 21-24.

${ }^{72}$ Bishop E. K. Kotowicz of Smolensk to Višnioveckis, letter of Apr. 1702, Vilnius (a copy), LMAB RS, f. 17, b. 177, fos. 328-328v.

${ }^{73}$ Pociejus to Radvila, letter of 30 (?) Apr. 1702 from the military camp, $A G A D, \mathrm{AR}, \mathrm{V}$, nr. 11913 / I, pp. 93-99. Višnioveckis' answer to bishop E. K. Kotowicz of Smolensk, Valazhin, 3 May 1702 (a copy), LMAB RS, f. 17, b. 177, fos. $328 v-329$. 
between Sweden and Augustus II and the Republic, in the internal Lithuanian conflict in the spring of 1702 the endeavours to pass from the armed confrontation to negotiations failed. The difference was in that that in the principal conflict the initiative of the talks belonged to Augustus II and the Republic and Charles XII only rejected the proposals, while in the Lithuanian internal conflict the situation was reverse. Negotiations foundering K.J. Sapiega issued a universal obliging the military serving under the field hetman Višnioveckis to pass under the command of the grand hetman of the GDL (i.e. under his command). ${ }^{74}$

A favourable situation in the theatre of military operations did not stimulate the Republicans to begin negotiations with the Sapiegas. The principal Swedish forces marched through Grodno towards Warsaw and thus receded from Lithuania and the garrisons left in Vilnius, Kaunas and Žemaitija. The regiments of the drafted gentry began arriving at the military camp of the Republicans. On 14 May the regiments of the powiats of Ašmena, Minsk and Polotsk were in the camp. The following week the regiments of the other palatinates and powiats were expected. ${ }^{75}$ The financial situation of the Republican army also began to improve gradually. In late April the Republican leaders had expressed fears that their army might disperse or be enticed by the Sapiegas, ${ }^{76}$ while in May matters were improving. Višnioveckis imposed 100,000 florins in reparations on the Duchy of Slutsk for which he had to make excuses to K.S. Radvila. ${ }^{77}$ However, most important was the support obtained by the Republicans from Moscow. On 29 April 1702 a Russian envoy (goniets) arrived at the military

${ }^{74}$ K.J. Sapiega's universal to the troops of the GDL under Višnioveckis' command, Vilnius, 10 May 1702 (a copy), ibid., fos. 329v-330.

${ }^{75}$ L.K. Pociejus to Radvila, letter of 14 May 1702 from Valazhin, ibid., pp. $115-118$.

76 'Tu u nas straszna [...] w woysku ledwo możemy utrzymać, bo całe niepłatni musieliśmy na Słuck sto szesdziesiąt tysięcy nałożyć. Bo Bóg widzi, żeby się albo rozpelzło, albo gdzie indzi przedało woysko', Višnioveckis to Radvila, letter of 28 Apr. from the environs of Valazhin, ibid., nr. 17503 / I, pp. 44-46.

${ }^{77}$ Ibid. The Dukedom of Slutsk was a private possession of Elisabeth Augusta Wittelsbach, a minor daughter of the already dead Liudvika Karolina Radvilaite (Ludwika Karolina Radziwiłłówna) and Carl Philip Wittelsbach, duke of Neuburg and count palatine of Rhein. Slutsk, like the entire legacy of Radvilaite, the so-called Neuburgian heritage, was in charge of the chancellor of Lithuania K.S. Radvila after the battle of Valkininkai and the decision of Valkininkai (24 Nov. 1700). 
camp with a promise of a subsidy for the Republican army if it participated actively in the war against the Swedes. ${ }^{78}$ At the beginning of May several thousand Ukrainian Cossacks arrived from Russia. ${ }^{79}$

Russia not only encouraged the Republicans to continue intensive military actions against the Swedes, it also started to form its own image as a reliable and useful partner of the Lithuanian Republicans. Russian support became even more important for the Republicans than that of King Augustus II or Poland. ${ }^{80}$ The disappointment of the Republicans with both the king and Poland was enormous at that time. The expectations that Augustus II would come with Saxon and Polish forces to help at Brest Litovsk turned out to be wrong. ${ }^{81}$ Therefore, when the Swedes were already marching through Poland, the Lithuanian Republicans wrote that they would watch how Poland would meet 'the coming guest, who had already occupied Lithuania by the right of the invader and how it would abide by the postulates of the union with Lithuania', ${ }^{82}$ i.e. whether Poland would fight against the invaders together with Lithuania or would yield to them and leave the Lithuanian Republicans alone in the struggle. In the Republican camp dissatisfaction was aired concerning unfavourable terms for proposed Saxon support by

\footnotetext{
${ }^{78}$ Pociejus to Radvila, letter of 30 (?) Apr. 1702 from the military camp, ibid. nr. 11913 / I, pp. 93-99.

${ }^{79}$ Višnioveckis to Radvila, letter of 5 May 1702 from the environs of Valazhin, ibid., nr. 17503 / I, pp. 21-24. In it Višnioveckis wrote that the Cossacks had already passed Bykhov, the fortress at the Dnieper, Orsha powiat; 'Kozaków codzień iuż wyglądamy, tak kładę, że w tych dniach nadciągano', Pociejus to Radvila, letter of 14 May 1702 from Valazhin, ibid., pp. 115-118.

${ }^{80}$ On the rapprochement between the Republicans of the GDL and Russia and the first agreement concerning Russian military support for the Republicans in 1702, see G. Sliesoriūnas, 'Starania dyplomacji rosyjskiej o wciagniecie Rzeczypospolitej Obojga Narodów do wojny ze Szwecją w roku 1702 a problem integralności państwa polsko-litewskiego', Polska wobec wielkich konfliktów w Europie nowożytnej. $Z$ dziejów dyplomacji i stosunków międzynarodowych $w$ XV-XVIII wieku, ed. R. Skowron (Cracow, 2009), pp. 465-481.

81 'Krul Jmść tesz woysko koronne sciągać ma pod Brześć[...], bo na nas iednich wstrzymować tey potendzie przycienszko', Višnioveckis to Radvila, letter of 5 May 1702 from the environs of Valazhin, $A G A D$, AR, V, nr. 17503 / I, pp. 21-24.

82 'my tu obstacula uspokoiwszy tak suppono, że w tropy za nim [following Charles XII - G. S.] puydziemy, chcąc się przypatrzić, iako też Ichmość Panowie Koronni tego gościa przymować będa, który nasz kray iure hostilitatis zwoiował, y iako w tym vincula unionis dotrzimywać będą, Pociejus to Radvila, letter of 24 Apr. 1702 from Alšènai, ibid., nr. 11913 / I, pp. 111-114.
} 
auxiliary forces. ${ }^{83}$ Besides the rumours about King Augustus II's attempts to come to terms with Charles XII at the expense of the Republic discontented and demoralized the troops. ${ }^{84}$ When it became evident that the Swedish troops most probably would march from Vilnius to Poland to support their king, L.K. Pociejus wrote ironically to Radvila that the army of the Lithuanian Republicans would not regret if Poland also had to fight, since when Lithuania needed help the Poles did not believe it. ${ }^{85}$

\section{The Retreat of the Swedes and the Sapiegas from Vilnius}

Mörner wanted to leave Vilnius as soon as his Nieroth's forces came to themselves. ${ }^{86}$ Yet on 28 (18 Swedish style) April Mörner received a royal directive, dated 25 April (15 Swedish Style). The king instructed Mörner to remain at Vilnius for the time being and 'communicate' with Hetman Sapiega in regard to the use of the troops and their supplies. This order was a result of the influence of the hetman's brother - the grand treasurer, who accompanied the Swedish king. Mörner immediately asked for the hetman's suggestions in writing ${ }^{87}$ and stayed in Vilnius for some time in order to support Sapiegas' action with the Tribunal. The hetman answered as follows: In order to bring the Tribunal in Vilnius to a more favourable composition he wanted to see Višnioveckis defeated in a military action or to have some sort of agreement with him. Sapiega even believed that Višnioveckis was ready to yield. Mörner considered this to be overoptimistic and considering the difficulties he had in

83 'O Reymenta saskie do nas z nowu gorszo mi głowę, a to naybarziey o zapłatę żebym deklarował, a tu y swoim dać nie masz co. Co y w tym za utrapienie cierpię wypowiedzieć nie podobna. Już [...] na ustatku chcą we mnie powiadaiąc, żem w Warszawie miał deklarować, że iak postanowiono Ichmość Panowie Hetmani Koronni, to y ia tak powinienem przyiąć. Tam dwanaście przyięli Reymentów. A zatym y mnie koniecznie iniungunt osm przyiąć. A mnie się o tym nigdy ani sacto', Pociejus to Radvila, letter of 30 (?) Apr. 1702 from the military camp, AGAD, AR, V, nr. 11913 / I, pp. 93-99.

${ }^{84}$ Pociejus to Radvila, letter of 24 Apr. 1702 from Alšènai, ibid., nr. 11913 / I, pp. 111-114.

85 '[...] Wileńscy lubo czynio pozór iscia swego w te y w owe stronę, boiemy się barzo, że oddawszy slaki za swym Krulem nie pociagnęli, choć ci z naszey strony nie barzo tesknili byśmy, chocby y tam poszli, niechby też teyże kiedy dostało się y Koronnym, ponieważ nam nie wierzali', Pociejus to Radvila, letter of 14 May 1702 from Valazhin, ibid., pp. 115-118.

${ }^{86}$ Carl von Rosen, Bidrag till kännedom om de händelsser ..., vol. 1, p. 35.

${ }^{87}$ Ibid. 
supplying the troops, he was relieved to receive on 11 (1 Swedish Style) May the king's order (dated April 26 Swedish Style) to proceed to Warsaw immediately. The hetman declared that he wanted to go with Mörner, and as the king's order also said that Mörner should take every opportunity to strike at Višnioveckis; if such was hetman's wish, Mörner agreed to march to Ašmena. Mörner prepared his troops and left Vilnius on 13 (3 Swedish Style) May. ${ }^{88}$ The forces of the Lithuanian Republicans growing in the military camp and the main Swedish army retreating further to Poland, in Vilnius the situation of the Swedish corps and the forces of the Sapiegas became hazardous. Besides, in view of the imminent battle with the army of Augustus II in Poland Charles XII needed the majority of his troops still stationed in Lithuania. Therefore, a decision was made to leave the capital of Lithuania and keep closer to the forces of Charles XII. Seeking to ensure a safe march the Swedes tried to mislead the Republicans by imitating their retreat from Vilnius several times in various directions: towards Druia allegedly against Russian forces, towards Ašmena and Valazhin in the direction of the military camp of the Republicans. However, after having marched no more than a mile and a half they returned back to the city. ${ }^{89}$ Such manoeuvres prevented the Republican leaders from ascertaining the real plans of the Swedes and L.K. Sapiega and determining the exact size of the corps left in Vilnius. On 15 May 1702 Višnioveckis wrote to the chancellor of Lithuania that he was sure that of 8,000 Swedes stationed in Vilnius 3,000 horsemen had been sent in the directions of Druia against the auxiliary Russian forces and he doubted the success of the Swedish action against Muscovy. The field hetman of Lithuania had also heard about Swedish intentions to march against the Republican army; he hoped to gain more accurate information after his reconnaissance raid of 1,000 men in the direction of Vilnius. ${ }^{90}$ The misleading manoeuvres of the Swedish corps stationed in Vilnius

${ }^{88}$ Ibid., pp. $35-36$.

${ }^{89}$ Pociejus to K. S. Radvila, letter of 24 Febr.1702 from Alšènai, $A G A D, \mathrm{AR}$, V, nr. 11913 / I, pp. 115-118.

90 'Woyska Szwedzkiego w Wilnie osmium tysięcy, s których trzy tysięcy kawalerii posło tydzien jutro (tomorrow it will be a week since their departure - G. S.) ku Drui. Znać na przeciwko Moskwie, ale nie kładę, aby co wskurali. Tu ku nam mislą również, o czym ieszcze podiazdów czekamy lepszey od nich informacyi, w tych dniach s tysiąc koni ku Wilnowi wisyłam', Pociejus to Radvila, letter of 15 May 1702 from Valazhin, ibid., nr. 17503 / I, pp. 17-20. 
prevented Višnioveckis from implementing his undertaking - to take all of his troops out of the camp and to march into the rear of the main Swedish army led by Charles XII. ${ }^{91}$ This solution had been found already in the middle of May.

After several misleading manoeuvres in the middle of May, most probably on 13 or 15 of May ${ }^{92}$ (sometimes the beginning of May is erroneously indicated), ${ }^{93}$ the Swedish corps and K.J. Sapiega's troops left Vilnius, and their leaders knew well that the final location of their march was Warsaw. ${ }^{94}$ Before leaving the city the Swedes demanded one more reparation, this time a smaller one. ${ }^{95}$ The Swedes also sank the heavy cannons of the Vilnius arsenal. ${ }^{96}$ Some historical works wrongly indicate not only the date of the Swedish withdrawal from Vilnius but also its direction stating that Mörner's corps marched to Poland from Vilnius directly through Grodno. ${ }^{97}$ The most significant inaccuracy is the statement that after the retreat of the Swedish corps from Vilnius in May, K.J. Sapiega's forces stayed in the city even as late as August ${ }^{98}$ and went to Poland through Vilkaviškis, Grodno and Białystok. ${ }^{99}$ Actually, all Swedish and Sapiegian forces located at that time in Vilnius left the city in the middle of May (probably on 13 or 15) and took a rather

${ }^{91}$ Pociejus to Radvila, letter of 14 May 1702 from Valazhin, ibid., nr. 11913/I, pp. $115-118$.

92 The day indicated by Gustaf Jonasson was 15 May.

${ }^{93}$ Dundulis wrote that the Swedes left Vilnius on 3 May - this mistake is again due to the differences of the Swedish and Gregorian calendars, cf. Dundulis, Švedu feodalu isiveržimai, p. 124.

${ }^{94}$ Łakociński, Magnus Stenbock, p. 30. Stenbock wrote to his wife from Vilniaus on 2 (12) May 1702: 'Morgen nach Warschau wils Gott'.

${ }^{95}$ The city had to pay 720 thalers, Kraszewski, Wilno od poczatków jego, t. 2, pp. 82-83.

96 'Szwedzkie woysko z jenerałem Mernerem w Wilnie zabrawszy armaty wszystkie iedne potopili, drugie z sobą wziąwszy ruszyli się z Wilna, wespół z nimi y P. Woiewoda Wileński w kray oszmiański przeciwko woyska litewskiego, chcąc koniecznie mieć bitwę z Xięciem Hetmanem', $L M A B$ RS, f. 17, b. 177, fo. 330.

${ }^{97}$ Dundulis, Švedu feodalu isiveržimai, p. 124. The movement of the army is presented in the same way in the schemes of the military actions, ibid.

${ }^{98}$ Ibid., p. 125. 'Understanding that his forces were insufficient hetman K.J. Sapiega (and his 3,000 men) together with the Swedish unit (Gen. J. Maydel's corps G. S.) again retreated from Vilnius to Poland in August'. That the Swedish army retreated from Vilnius leaving the city in the hands of K.J. Sapiega is also mistakenly indicated by Jurginis, Merkys, Tautavičius, Vilniaus miesto istorija, p. 176.

${ }^{99}$ Dundulis, Švedu feodalu isiveržimai, p. 125. 
unusual direction - towards Ašmena, i.e. eastwards. It is possible that K.J. Sapiega and the Swedes were going to fight the principal Republican forces. L.K. Pociejus had mentioned that the deserters from the Republican camp to K.J. Sapiega in their accounts to the palatine of Vilnius painted a gloomy picture of the situation in the Republican army; they stated that its soldiers were dissatisfied, they did not receive salaries and began dispersing and going home, the 'friends' of the cavalry regiments (i.e., the military enlisted on their own, usually members of the gentry who had their personal attendants) had departed to their manors and only their servants remained in the camp. In the camp many sympathized with the Sapiegas and the army of the palatine of Vilnius approaching they would doubtless go over to him. ${ }^{100}$

However, the development of events was different. The Swedish and Sapiegian army reached Ašmena on 18 May ${ }^{101}$ and clashed with a cavalry force of about 1,000 men sent by Višnioveckis on a reconnaissance mission. It was not a surprise attack, because the gentry of the Ašmena powiat, adherents of the Sapiegas, or in Višnioveckis' words 'old traitors', warned the palatine of Vilnius about the approaching Republicans. ${ }^{102}$ The support lent to the Sapiegas in the Ašmena powiat where the influence of the Republicans was particularly strong shows that a continued presence of K.J. Sapiega in Lithuania encouraged his adherents and could revive the grouping supporting the Sapiegas. That accounts for the Sapiegas' success in forming rather large military units easily and quickly. Having caught several prisoners the Republicans retreated from Ašmena to their camp at Ivija. They were followed hard behind by the Sapiegan and

${ }^{100}$ Pociejus to Radvila, letter of 30 May 1702 from the camp at Bokštai, $A G A D$, AR, V, nr. 11913 / I, pp. 119-122.

101 'ie 18 Maia Merner jenerał z woyskiem szwedzkim y P. Wda. Wileńskim w Oszmianie stanął y tam 3 dni stał', LMAB RS, f. 17, b. 177, fo. 330.

102 '[...] pewnie by szczęsliwie gosciły, gdyby nie złość niektórych szlachta, która [...] częscią iako dawni zdraici znać obiawali Sapieże', Višnioveckis to Radvila, letter of 30 May 1702 from the camp at Bokštai, $A G A D, \mathrm{AR}, \mathrm{nr} .17503$ / I, pp. 52-56; in the court of August II it was believed that the Sapiegas were going to enlist their supporters from the gentry of Ašmena powiat: 'JMP. Wda Wilen. Hetman W. Litt. iuż wyszedł z Wilna z temi czterema tysiącami Szwedów, których miał przy sobie, et extremis casibus deklarował się committere. Miał się lokować pod Oszmiany, czekaiąc na sciaganie ludzi swoich y certum sequitum szlachty, ktorą sobie obiecywal, aby iunctis viribus mógł pospieszyć do Warszawy', Kczewski to Radvila, letter of 7 June 1702 from Cracow, ibid, nr. 6589, pp. 100-104a. 
Swedish forces which set up their camp in Alšènai. Informed about the approaching enemy Višnioveckis decided not to retreat (what the Swedes and the Sapiegas had expected) but to join battle. The field hetman gave orders to withdraw the wagon train to the rear and to prepare for battle. At that time the distance between the two armies was only four miles. Višnioveckis waited for the Swedes and K.J. Sapiega to go into battle first. They, however, to Višnioveckis' amazement, suddenly started marching to the south towards the River Nemunas bypassing the Republican army. They managed to cover about six miles before the field hetman understood what was happening. Then Višnioveckis started persecuting the Swedish corps and was going to do battle during the crossing. ${ }^{103}$ The vanguard of the Republican army led by Valavičius was sent to persecute the Swedes. However, the Swedes managed to cross the Nemunas and avoid doing battle with the Republicans for the second time. They built a bridge at the settlement of Mikolaevo to the west of the town of Lubch in four hours (according to the Swedes it took them eight hours to build the bridge). ${ }^{104}$ Failing to disrupt the crossing operation, Valavičius nevertheless did not lose hope and attempted to perform an act of sabotage and to capture K.J. Sapiega having supper at the estate of Lubch. The palatine of Vilnius was warned of the imminent danger at the last moment and 'leaving the spoons on the table' hastily retreated to the former Swedish camp a quarter of a mile away. The Swedes were in a state of preparedness the whole night waiting for the attack which after all did not take place. ${ }^{105}$ On Sapiega's request Mörner continued his march southeast past Novogrodek to 'Poluze' where he arrived on 31 (21 Swedish style) May. During this manoeuvre Sapiega asked Mörner several times to march to Slutsk in order to capture the fortress and the town. Mörner considered that this would divert him too much from his march towards Warsaw and instead continued in a southwesterly

${ }^{103}$ Višnioveckis to Radvila, letter of 30 May 1702 from the camp at Bokštai, ibid., nr. 17503 / I, pp. 52-56; Pociejus to Radvila, letter of 30 May 1702 from the camp at Bokštai, ibid., nr. 11913 / I, pp. 119-122.

${ }^{104}$ Łakociński, Magnus Stenbock., p. 31. After this operation Mörner acquired a reputation as a first-class bridge builder; on 29 June 1702 he built a bridge across the Vistula at Kazimierz, and afterwards he was entrusted with similar tasks.

${ }^{105}$ Višnioveckis to Radvila, letter of 30 May 1702 from the camp at Bokštai, $A G A D, \mathrm{AR}, \mathrm{V}, \mathrm{nr} .17503$ / I, pp. 52-56; Pociejus to Radvila, letter of 30 May 1702 from the camp at Bokštai, ibid., nr. 11913 / I, pp. 119-122. 
direction towards Slonim and Pruzhanna to Kamieniec-Litewski. ${ }^{106}$ Sapiega accompanied the Swedes and in every possible way tried to persuade Mörner to march eastwards in pursuit of Višnioveckis. Mörner did not want to do this and wrote to the king on 26 (16 Swedish Style) May asking for advice on how to deal with the hetman. He received the king's reply instructing him to march towards Cracow and leave the Nyland cavalry regiment for the protection of the hetman. K.J. Sapiega stayed in the palatinate of Brest Litovsk, and Mörner's corps was in time to join the main forces of Charles XII at Kelcy on 18 July 1702 on the very eve of the battle of Kliszow on 19 July 1702.

The retreat of the Swedes and K.J. Sapiega was rather risky. In the sources the size of the corps was indicated variously $-10,000$ men (Zawisza) ${ }^{107}, 8,000$ (L.K. Pociejus, Višnioveckis) ${ }^{108}$ or 4,000 (Kczewski). ${ }^{109}$ It is known that there were about 61,000 men in the Swedish army at that time. Charles XII invaded the Republic with 21,000, ${ }^{110}$ and in Livonia, Estonia and Finland 24,700 men and 8,000 men of local militia were recruited against the Russians. ${ }^{111}$ Thus, a more reliable estimate of the size of the Swedish corps in Vilnius would be minimal, i.e. about 4,000. ${ }^{112}$ The strength of units under Mörner's command could be estimated as follows: the original units comprised the Dalregementet (infantry) of 1,200 men (Stenbock's regiment) and Östgöta kavalleriregemente (cavalry) of 1,000 men (Mörner's regiment). Later reinforcements were Ekeblad's detachment, from the start 600 infantrymen from the regiments of Podbusch and Lewenhaupt and 200 men from the Nyland cavalry regiment. When leaving Biržai on 13 (3 Swedish

${ }^{106}$ Carl von Rosen, Bidrag till kännedom om de händelsser ..., vol. 1, pp 35-36.

107 [Zawisza], Pamiętniki Krzysztofa Zawiszy, p. 213.

${ }^{108}$ L.K. Pociejus to Radvila, letter of 20 Apr. 1702 from the military camp, $A G A D, \mathrm{AR}, \mathrm{V}, \mathrm{nr} .11913$ / I, pp. 107-110; Višnioveckis to Radvila, letter of 5 May 1702 from the environs of Valazhin, ibid., nr. 17503 / I, pp. 21-24.

${ }^{109}$ Kczewski to Radvila, letter of 7 June 1702 Cracow, ibid, nr. 6589, pp. 100-104a.

${ }^{110}$ R.I. Frost, The Northen Wars. War, State and Society in Northeastern Europe, 1558-1721 (Harlow, etc., 2000), p. 248.

${ }^{111}$ O. Urbonas, Didžiojo Šiaurès karo frontas Lietuvoje, t. 1, Karys, 1963 (Lietuvos karo istorijos raštai, nr. 3), p. 19.

112 This number is also indicated by Jacek Burgowicz-Nowicki, Piotr I, August II i Rzeczpospolita 1697-1706 (Cracow, 2010), p. 280. 
Style) March another 350 men from the Nyland cavalry regiment accompanied him. In Anykščiai he took 150 dragoons (or maybe even 400) from Albedyhl's regiment. Such were the Swedish units when Pociejus attacked the Swedes in Vilnius (16 April). There were some later reinforcements. Ekeblad was supposed to have been accompanied by 400 'walachians' belonging to Sapiega. The first two regiments most certainly comprised not more than 1,200 and 1,000 men. A hundred men from Mörner's regiment had been sent with Hummerhielm in the autumn of 1701, others had been sent with Meijerfelt at about the same time. It is most probable that at the start Mörner's regiment could not have had more than 800 men. Dalregementet lacked 86 men in August 1701, and 160 new recruits were sent in the spring of 1702 . Thus, during the stay in Vilnius it could have consisted of around 1,050 men. Consequently, when Pociejus attacked Vilnius there could have been around 3,000 soldiers under Mörner's command. These figures do not include officers, officer's servants, non-commissioned officers and so on. Later Nieroth arrived with Smålands kavalleriregemente (cavalry) of 1,000 soldiers, Västerbottens infanteriregemente (infantry) of 1,056, and Kalmar infanteriregemente (infantry) of 1,100. The Swedish forces must have included some more units. It is estimated that Mörner and Stenbock arrived just before Kliszow with about 5,000 men, which consisted of the above-mentioned forces minus the Nyland cavalry regiment which had been sent with the hetman Sapiega. Thus, at Vilnius there were between 5,500 and 6,000 Swedish and Finnish soldiers. The officers, non-commissioned officers, civilian personnel, officer's servants, supply train personnel etc. should be added to those numbers. ${ }^{113}$ Due to risky but successful manoeuvres and the relevant information furnished by the Sapiega adherents ${ }^{114}$ the Swedish corps avoided defeat which could have changed the course of the Republican conflict with the Sapiegas if not the final outcome of the war.

The activities of the Sapiegas in March-May 1702 finally broke off the contacts between the court of Augustus II and the official

113 The estimation was made by Bengt Nilsson.

${ }^{114}$ K.J. Sapiega's troops also were not numerous: ‘ P. Wda Wileński w Olszanach stanął $\mathrm{w}$ klasztorze $\mathrm{u}$ franciszkanów, maiąc koło siebie dostatnie warty szwedzkie, ale swoią własną assistencyą bardzo szczupłą miał dwie chorągwie wołoskie, iedną rotmistrzostwa P. Boryczewskiego, drugą rotmistrzostwa P. Kuncewicza; dragonyi koni ze 100 y dworskich nie wiele', $L M A B$ RS, f. 17, b. 177, fo. 330v. 
government of the Republic. At the end of March the court still kept alive the hope that the Sapiegas would not dare fight openly against Augustus II and that soon there would be a chance to come to an agreement with the Swedes and to cease hostilities. ${ }^{115}$ At the beginning of April it was stated that the Sapiegas had already fallen out of favour with the people of Augustus II's court, and in particular with the palatine of Marienburg Jerzy Przebędowski, a senator of Poland, closest to the king. ${ }^{116}$ After the occupation of Vilnius and the start of the Swedish march towards Warsaw an opinion prevailed in the king's court that the Sapiegas should take the blame for encouraging Charles XII, so far inclined towards reconciliation, to start a total attack on the Republic. ${ }^{117}$ After the Sapiegas' actions in Vilnius and their protracted cooperation with the Swedes the court of Augustus II considered that the Sapiegas lost the last chance to make peace with their king. ${ }^{118}$

The first occupation of Vilnius during the Northern War lasted a little more than a month. But that was far from sufficient for the Sapiegas to rally their grouping in Lithuania and to strengthen their positions in the struggle against the Lithuanian Republicans. The Sapiegas also failed to negotiate with the Republicans from a position of strength by exploiting all advantages offered by the control of the capital of Lithuania. When the troops of the Swedes and the Sapiegas retreated to the western regions of the GDL, military activities proceeded along the communicative line Riga - Mitava - Kaunas - Grodno - Brest Litovsk, linking Charles XII's army in Poland with his support bases in Livonia. The Lithuanian Repub-

115 'Ichmm PP. Sapiehowie w Dobrach swoich na Żmudzi subsistunt, którzy ieżeli non sociabunt consilia sua z Królem Szwedzkim, prędkiego się spodziewamy pokoiu', Kczewski to Radvila, letter of 26 March 1702 from Warsaw, $A G A D$, AR, V, nr. 6589, pp. 55-57.

116 'JPP. Sapiehowie wcale JP. Wdy Malborskiego zdrowe y życzliwe rady zarzucili et omne commercium abruperunt. Czynił dosyć JP Woiewoda, coś kiedy nulla tractabilis arte zawziętość odio verba momentu habebunt. Y tak się z JP Woiewodą szczera y stateczna przyiaźń zakończyła‘, Kczewski to Radvila, letter of 5 May 1702 from Warsaw, ibid., pp. 62-65.

117 'Był Król JM. Szwedzki dispositissimus do pokoiu y na iednę tylko czekał legatią Rzeczy P. aby z honorem wyszedł z tey intrygi [...]', Kczewski to Radvila, letter of 11 Apr. 1702 from Warsaw, ibid., pp. 73-76.

118 'JPP. Sapiehowie iusz podobno tego nie odrobią, co się stało: disaque ferratis evolvent pensis', Kczewski to Radvila, letter of 5 May 1702 from Warsaw, ibid., pp. 85-87. 
licans, backed by Russia, soon re-established their preponderance in the GDL and began persecuting the gentry who had unwarily expressed their sympathies for the Sapiegas in the spring of $1702^{119}$ when it seemed that with the help of Charles XII these noblemen would recover their influence and power in the country.

Translated by Alfoncas Laučka

\section{Author Details}

Dr Gintautas Sliesoriūnas is a member of the Department of the History of the Grand Duchy of Lithuania, the Lithuanian Institute of History. He researches the political and social situation in Lithuania in the 17th and 18th centuries.

Address: Lithuanian Institute of History, Kražių 5, LT-01108 Vilnius, Lithuania

Email: slgintas@centras.1t

\section{PIRMOJI VILNIAUS OKUPACIJA ŠIAURĖS KARO METAIS (1702 M. BALANDIS-GEGUŽĖ)}

Santrauka

\section{GINTAUTAS SLIESORIŪNAS}

Šiame straipsnyje bandomas rekonstruoti karo veiksmų ir diplomatinių iniciatyvų, susijusių su pirmaja Šiaurès karo metais Lietuvos Didžiosios Kunigaikštystės sostinès - Vilniaus miesto - okupacija, vaizdas. Buvo pasitelkti pirminiai šaltiniai - Lietuvos respublikonų kariuomenès vadų - Lietuvos lauko etmono Mykolo Servacijaus Višnioveckio ir Lietuvos didžiojo raštininko Liudviko Konstantino Pociejaus korespondencija su Lietuvos kancleriu Karoliu Stanislovu Radvila. Tai leido patikslinti ankstesnius istoriografijoje paplitusius teiginius, kurie dažniausiai rèmėsi amžininkų dienoraščiais ir atsiminimais. Buvo išanalizuoti Lietuvos respublikonų karo vadų operaciniai planai Vilniaus praradimo išvakarèse, Lietuvos nuostoliai (artilerijos), patirti, kai $1702 \mathrm{~m}$. balandžio 5 d. Vilnių užèmė švedų kariuomenè. Išsamiai išnagrinètas Lietuvos respublikonų karo vadų sumanymas surengti Vilniaus kontrpuolimą ir Vilniaus kautynès, ịvykusios $1702 \mathrm{~m}$. balandžio $16 \mathrm{~d}$. (pirmają Velykų diena). Buvo nustatyta, kad L. K. Pociejaus vadovautame reide į Vilnių dalyvavo 2 tūkst. ir keli šimtai karių. Planuotų 4 tūkst. karių suorganizuoti nepavyko dèl prastos Lietuvos respublikonų kariuomenès būklès. Buvo paneigtas istoriografijoje pasitaikantis teiginys, kad reidas i̇ Vilnių buvo pagalbinio pobūdžio ir turèjo tik atitraukti švedų dėmesi nuo M. S. Višnioveckio neva $1702 \mathrm{~m}$. balandžio $17 \mathrm{~d}$.

119 'Litwa zaś całe księstwo znowu opanowała, partyzantów sapieżyńskich dwory i wsie rabując i paląc [...]. Po wielu wsiach prawie przyjaciele domu sapieżyńskiego zawiedzeni i opuszczeni, zostali jako łup szalonych. Żal się Boże niepoczciwie pozabijanych tak godnych i zacnych ludzi', [Zawisza], Pamiętnik Krzysztofa Zawiszy, pp. 213-214. 
surengto reido į Kauną. Buvo įrodyta, kad Kaunas tuo metu nebuvo pultas. Aptartos švedų represijos Vilniaus mieste po $1702 \mathrm{~m}$. balandžio 16 d. kautynių. Straipnyje išanalizuotos Lietuvos didikų Sapiegų, rèmusių Švediją šiame konflikte, politinès ir diplomatinès iniciatyvos, kurių jie ėmèsi, atvykę i švedų užimtą Vilnių. Sapiegos švedų pagalba bandė Lietuvos Didžiojoje Kunigaikštystėje atkurti savo įtaką, prarastą vidaus karo Lietuvoje su savo antagonistais - Lietuvos respublikonais - metu (po 1700 m. lapkričio 18 d. i̇vykusio Valkininkų mūšio). Sapiegos bandè panaudoti savo tikslams Lietuvos Vyriausiaji Tribunolą, pamėgino „iš jègos pozicijų” susitarti su savo priešais - Lietuvos respublikonais, pasinaudodami laikinu pranašumu, kurị jiems suteikè Lietuvos sostinės kontrolè. Respublikonai kategoriškai neatmetė Sapiegu pasiūlymo derètis, bet tokių derybų vengè. Ilgainiui Lietuvos respublikonų kariuomenè, pasitraukusi iš Vilniaus į Smurgainių-Valažino-Alšènų-Ivijos apylinkes, atkūrè savo jẻgas ir sustiprèjo. O švedų ir jiems talkinusių Sapiegų padètis Vilniuje tapo nesaugi. Buvo išsamiai aptartas švedų ir Sapiegų kariuomenès pasitraukimas iš Vilniaus, Sapiegų bandymas mobilizuoti savo šalininkų paramą Ašmenoje, švedų ir Sapiegų kariuomenès manevras Ašmenos-Alšènų-Lubčos rajone, dèl kurio jiems pavyko išvengti susidūrimo su pagrindinèmis Lietuvos respublikonų kariuomenès pajègomis, forsuoti Nemuno upę ir pasitraukti arčiau pagrindinès švedų armijos, vadovaujamos karaliaus Karolio XII ir tuo metu veikusios Lenkijos Karalystejje. 